\title{
PROFILE OF FLEXIBILITY OF HIGH SCHOOL STUDENTS IN MATHEMATICAL PROBLEM- SOLVING BASED ON PERSONALITY TYPE
}

\author{
Yenny Fitria Novitasari \\ Mathematics Education, Faculty of Mathematics and Natural Sciences, Universitas Negeri Surabaya \\ e-mail: yennynovitasari@mhs.unesa.ac.id \\ Rini Setianingsih \\ Mathematics Education, Faculty of Mathematics and Natural Sciences, Universitas Negeri Surabaya \\ e-mail: rinisetianingsih@unesa.ac.id
}

\begin{abstract}
Flexibility and problem-solving are two things that cannot be separated. One of the causes of differences in strategy in problem-solving is personality. This study is descriptive study using a qualitative approach. This study aims to describe the flexibility of high school students in mathematics problem-solving based on Keirsey personality types. The subjects in this study are four students with different types of personality. For data collection, this study used personality classification tests, mathematical ability tests, mathematical flexibility tests, and interview guidelines. The results show that the guardian student solves the problem using one strategy, namely the concept of addition and fraction multiplication and the answers obtained are incorrect. The artisan students solve the problem using two different strategies, namely drawing a picture and use a variable then the results of all answers are correct. Rational student solves the problem using two different strategies, namely use a variable and draw a picture, but cannot finish the second strategy. Idealist student solves the problem using two different strategies, namely use a variable and use direct reasoning then the answers are correct, but the second strategy is an advanced strategy.
\end{abstract}

Keywords: Problem-solving, flexibility, personality, Keirsey personality type.

\section{INTRODUCTION}

Mathematics is one of the subjects that has an important role in education. Along with this important role, mathematics is given at all levels of education and becomes one of the compulsory subjects in the national examination in Indonesia. According to Sumardyono (2004), mathematics is a tool in solving various problems both mathematical and daily problems. In NCTM (2000), it is explained that mathematics has five basic abilities, namely communication, reasoning, problem-solving, mathematical connections, and representation. The description above shows a linkage between mathematics and problemsolving.

Permendikbud Nomor 58 Tahun 2014 states that one of mathematics learning goals is that students can use concepts or algorithms as flexible as possible in solving problems. This shows that mathematics learning also focuses on increasing students' flexibility in solving problems. Flexibility in problem-solving refers to the ability of students to solve problems in one strategy, then using another strategy (Silver, 1997). The results of Arslan \& Yazgan (2015) study stated that students in solving nonroutine problems tend not to make changes to the strategy when the initial strategy used is wrong. Furthermore, based on Manurung (2011) it was shown that flexibility in solving problems of the impulsive and reflective student was still low. Flexibility can be observed through the results of student work by referring to the number of different and precise strategies that can be found to solve problems. The results above indicate that aspects of student flexibility in problem-solving still need further study. This study uses fraction material as a non-routine problem to assess students' flexibility because solving the problem can use more than one strategy.

Personality is a pattern of certain traits that are relatively permanent in a person's behavior (Feist \& Feist, 2011). Keirsey (1998) classifies personality into four types, namely guardian, artisan, rational and idealist. Every personality has different characteristics. According to Huitt (1992), artisan personality types have a better degree of flexibility in solving problems than guardian personality types. Furthermore, Prasetyo, Dwidayati \& Junaedi (2017) in his study explained that personality types of students influenced their flexibility in exploring mathematical ideas and tried various alternative strategies to solve mathematical problems.

In solving problems each personality type has a different way. The statement is supported by the study results of Siskawati (2013) which states that the differences 
in solving mathematical problems among students are caused by different personalities of each student. In line with this, the study results of Fitria (2014) state that each personality type has a different degree of flexibility in solving problems.

The description above brings up the question of how the relationship between different personality types with the flexibility students has in solving mathematical problems. Based on the above explanation, this study was conducted to determine the flexibility profile of junior high school students in solving mathematical problems based on personality types.

\section{METHODS}

The data analysis in this study will be presented as descriptive in nature study using a qualitative approach. This study aims to describe the flexibility of high school students in mathematics problem-solving, especially fractions based on personality types according to Keirsey. This study was conducted in SMP Negeri 1 Nganjuk in the even semester of the 2018/2019 academic year. The subjects in this study are four eighth grade students consisting of a student with a guardian personality type, a student with an artisan personality type, a student with a rational personality type, and a student with an idealist personality type.

To collect data, this study uses personality classification tests, mathematical ability tests, mathematical flexibility tests, and interview guidelines. Personality classification tests and mathematical ability tests are used to determine the study subject. While the mathematics flexibility test and interviews are used to describe flexibility in solving mathematical problems of study subjects.

Data analysis in this study consists of three steps namely data condensation, data display, and conclusion. For the analysis of mathematical flexibility tests in this study based on indicators of flexibility in solving problems adapted from Burger et al. (2008).

\section{RESULTS AND DISCUSSION}

The data collected in this study was conducted for three meetings in class VIII-9 of SMP Negeri 1 Nganjuk. The first meeting on Friday, 12 ${ }^{\text {th }}$ April 2019 was given a personality classification test to find out the personality types of each student. Based on the results, there were 13 students who have a guardian personality type, 9 (nine) students who have an artisan personality type, 2 (two) students who have a rational personality type, a student who has an idealist personality type, and 6 (six) students who have no tendency to one personality type. The second meeting on Tuesday, 16 ${ }^{\text {th }}$ April 2019 was given mathematical ability tests and selected four students who would be the subjects of the study with the results of an equivalent mathematical ability test for each personality type. The third meeting on Wednesday, $15^{\text {th }}$ May 2019 was given a test of mathematical flexibility to four study subjects. On the same day, it continued with task-based interviews to find out the profile of mathematics flexibility of junior high school students in solving mathematical problems.

To analyze the flexibility of students in solving mathematical problems, the following indicators adapted from Burger et al. (2008) are implemented.

Table 1. Indicators of Flexibility in Problem-solving

\begin{tabular}{|c|l|}
\hline No & \multicolumn{1}{|c|}{ Flexibility Indicator } \\
\hline 1 & $\begin{array}{l}\text { Select and set at least two different mathematical } \\
\text { problem-solving strategies }\end{array}$ \\
\hline 2 & $\begin{array}{l}\text { Implement the first strategy that has been selected } \\
\text { until the problem is resolved or until a suggestion } \\
\text { appears to take a new action }\end{array}$ \\
\hline 3 & $\begin{array}{l}\text { Implement other strategies to solve the problem } \\
\text { given }\end{array}$ \\
\hline
\end{tabular}

\section{Subject with guardian personality types}

Guardian student answers to the problem given can be seen from the following answer sheet pieces.

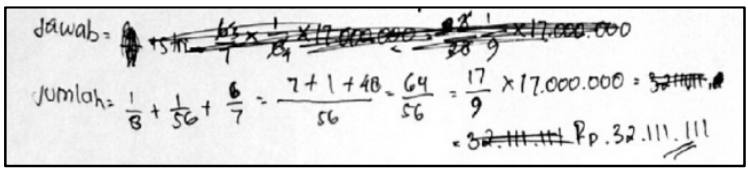

Figure 1. Fraction addition and multiplication strategy

Based on the answer sheet (Figure 1), guardian student works on the problem by summing all parts of the inheritance in the form of fractions of each known heir. In the process of summing up, an error occurs, so that the answers obtained are incorrect. The guardian student implements the first chosen strategy, which is the addition and multiplication of fractions to find the total inheritance of Mr. Aji distributed to the heirs (problem resolved) but the answer is wrong. The second strategy used by the guardian student to solve questions is as follows.

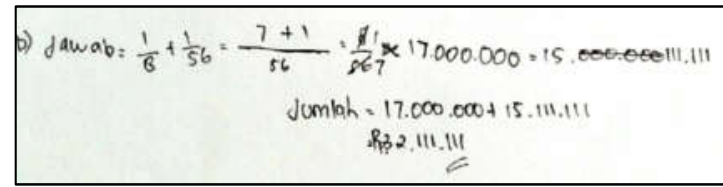

Figure 2. Fraction addition and multiplication strategy

Guardian student solve the same problem still with the same strategy as before, namely fraction addition and multiplication. It can be seen in Figure 2, that referring to the indicator of flexibility in problem-solving, namely choosing and setting at least two different mathematical problem-solving strategies, the guardian student only uses one strategy, namely the addition and multiplication of fractions for two points that have been worked on and the 
answers obtained incorrectly for both points that are. This is in line with Dewiyani's opinion (Panjaitan, 2015) which states that soft skills that must be improved by students with guardian personality types are flexible and varied in doing things.

\section{Subject with artisan personality types}

Artisan student answers to the problem given can be seen from the following answer sheet pieces.

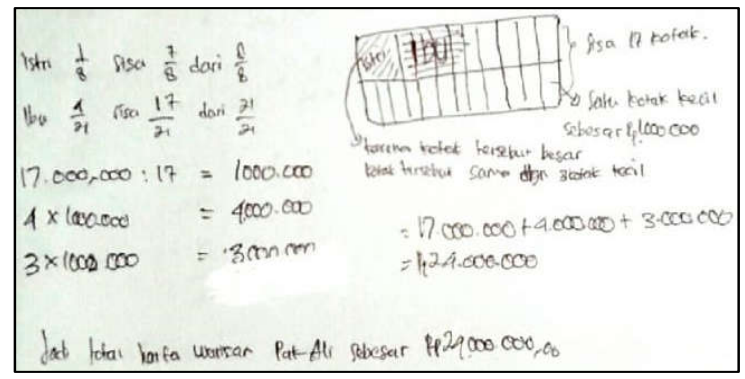

Figure 3. Draw a picture strategy

Figure 3 told us that artisan student works on the problem by making a large rectangular representing $\mathrm{Mr}$. Aji's total inheritance, then dividing it according to the rules of distribution of inheritance in the matter. After each part of the heirs is known, the final step is to add all total and the final result of Mr. Aji's inheritance in the form of money is Rp24.000.000. Artisan student implements the first strategy chosen, namely the strategy of drawing a picture smoothly and correctly until it is found the total inheritance of Mr. Aji to be distributed to the heirs (the problem is resolved). The second strategy used by the artisan student to solve questions is as follows.

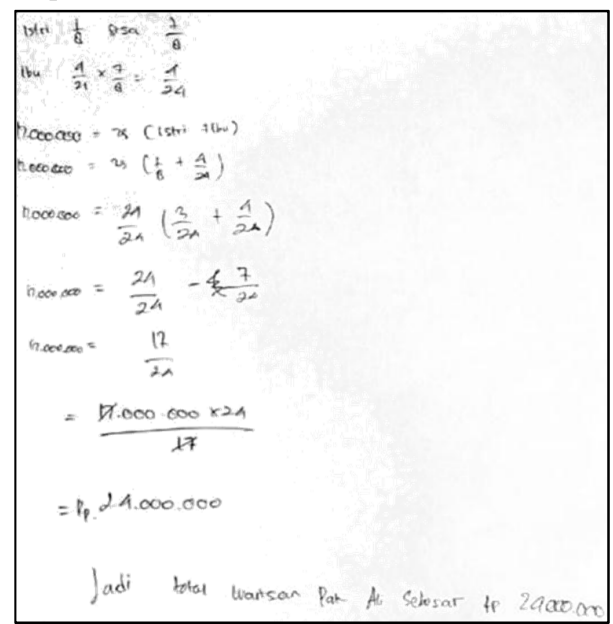

Figure 4. Use a variable strategy

Artisan student solves the same problem use another strategy namely use a variable. This can be seen from the artisan student's answer (Figure 4) which uses Mr. Aji total inheritance calculation as $x$ which is a new variable to facilitate students in solving problems. Referring to the indicator of flexibility in problem-solving, namely choosing and setting at least two different mathematical problem-solving strategies, the artisan student use two different problem-solving strategies namely, draw a picture and use a variable. Both strategies are carried out smoothly and the answers obtained are correct. This is in line with the opinion of Huitt (1992) which states that artisan personality types are more likely to choose to be flexible and adaptive. Individuals with artisan personality types have a better level of flexibility in solving problems compared to guardian personality types. A person is said to have an artisan personality type if he behaves sensing and perceiving. According to Keirsey (1998), perceiving is someone who is more flexible and acts freely to see the various opportunities that arise.

\section{Subject with rational personality types}

Rational student answers to the problem given can be seen from the following answer sheet pieces.

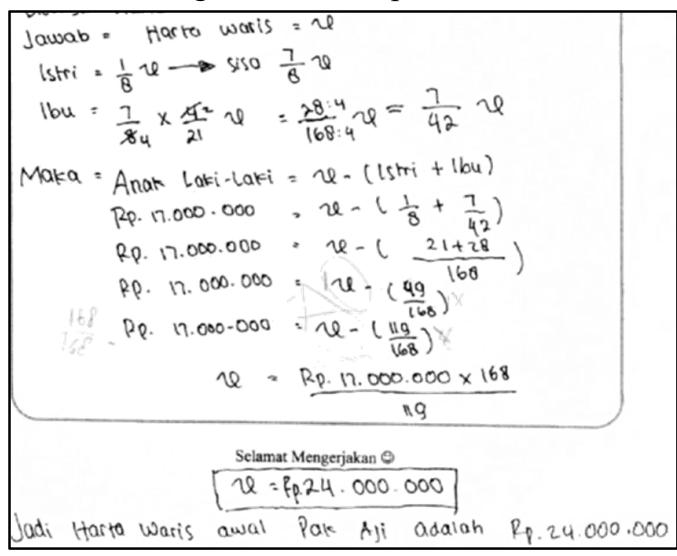

Figure 5. Use a variable strategy

It can be inferred from Figure 5, that rational student solve the problem by making a determination of the total inheritance as $x$. Because the exact amount of the inheritance of Mr. Aji's sons is known, the students make an equation regarding the distribution of inheritance. Then students solve the equation smoothly and correctly until the final result is obtained, namely the total inheritance of Mr. Aji in the amount of Rp24.000.000. The second strategy used by the rational student to solve questions is as follows.

Rational student solves the same problem use another strategy namely strategy of draw a picture, but because time has run out, students cannot successfully complete the answer for the second strategy used (Figure 6). Referring to the indicator of flexibility in problem-solving, namely choosing and setting at least two different mathematical problem-solving strategies, the rational student use two different problem-solving strategies namely, use a variable and draw a picture. The first strategy is done less smoothly but the answers obtained are correct, while the second strategy was not successfully resolved. In addition to the second strategy, namely draw a picture, rational students 
don't find new strategies. Rational students only use information that has been obtained from the answer using the first strategy.

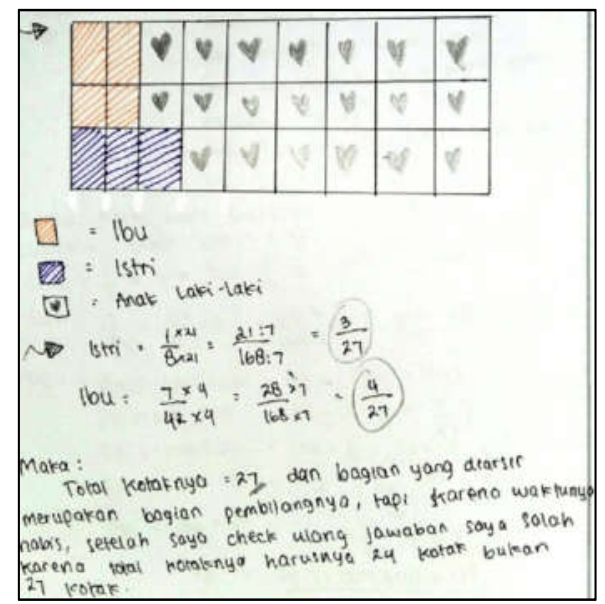

Figure 6. Draw a picture strategy

\section{Subject with idealist personality types}

Idealist student answers to the problem given can be seen from the following answer sheet pieces.

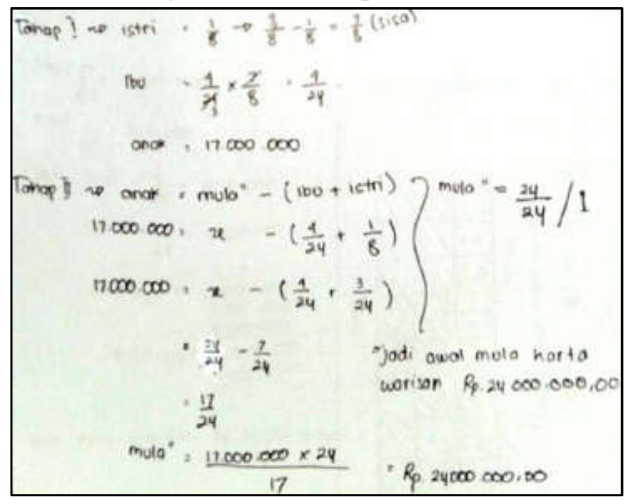

Figure 7. Use a variable

From Figure 7, we can see that idealist student work on the problem by dividing the process into two stages. Stage I to look for the division of each heir and stage II to determine the total assets of the original inheritance owned by Mr. Aji by making the initial total assets inheritance with $x$. Both of these stages are completed correctly by SI. So the answers obtained are also correct, namely Rp24.000.000. The second strategy used by the idealist student to solve questions is as follows.

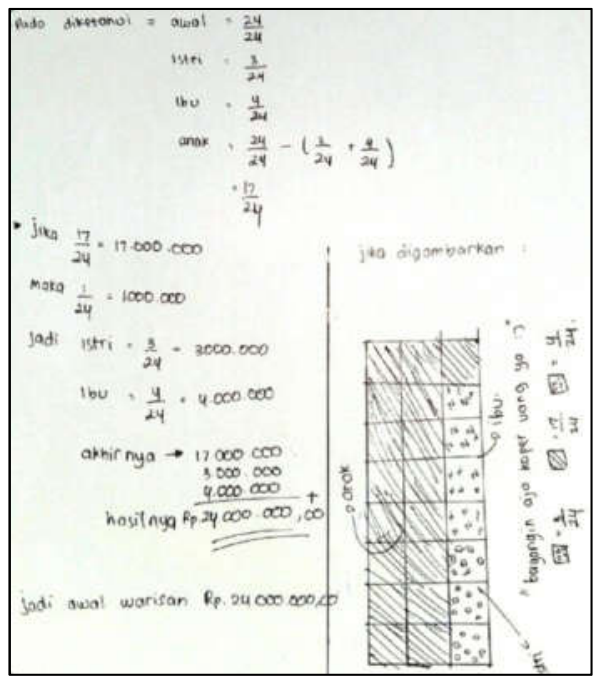

Figure 8. Direct reasoning strategy

Idealist student solves the same problem use another strategy namely use direct reasoning but by using information from the answer in the previous question to find Mr. Aji's total inheritance that was distributed to the heirs (Figure 8). Even though the answer is correct, the strategies used by students are not new strategies.

Referring to the indicator of flexibility in problemsolving, namely choosing and setting at least two different mathematical problem-solving strategies, the idealist student use different problem-solving strategies namely, use a variable and use direct reasoning. The two strategies used to get the correct answer. But for the second strategy, namely use direct reasoning, idealist students do not find new strategies. Idealist students use information that has been obtained from the previous answer and use direct reasoning to check the correctness of the answer.

\section{CLOSURE}

\section{Conclusions}

Based on the analysis and discussion of the data obtained during the study, the researcher may draw some conclusions as follows.

1. Students with guardian personality types solve problems twice by using one strategy to solve the same mathematical problem, namely the concept of addition and multiplication of fractions. But the results of the answers obtained from the two resolutions were wrong.

2. Students with artisan personality types use two different mathematical problem-solving strategies, namely draw a picture and use a variable. The two strategies for solving mathematical problems are carried out smoothly and the answers obtained are correct.

3. Students with rational personality types use two different mathematical problem-solving strategies, namely use a variable and draw a picture. Use a variable strategy is done less smoothly but the answers obtained 
are correct. While the draw a picture strategy is done by using the information on the answers obtained with the use of a variable strategy from not succeeding in solving the problem.

4. Students of the idealist personality type use two different problem-solving strategies, namely use a variable and use direct reasoning. The two strategies used to get the correct answer. But for the strategy of using direct reasoning, subjects don't find new strategies. The study subject used the information obtained from the answer using the use of a variable strategy.

\section{Suggestions}

Based on the study that has been done, there are suggestions as follows.

1. It is expected that mathematics learning in schools will pay more attention to how students' flexibility in solving mathematical problems. That way, students' mathematical flexibility can increase and furthermore, can improve student achievement.

2. It is expected that further study related to students' mathematical flexibility in problem-solving can expand study with consideration of the shortcomings in this study, so that it can provide more benefits in mathematics education.

\section{REFERENCES}

Arslan, C. \& Yazgan, Y. 2015. “Common and Flexible Use of Mathematical Non Routine Problem-solving Strategies." American journal of Educational Study. Vol. 3, No. 12, 1519-1523.

Burger, W.F., Musser, G.L. \& Peterson, B.E. 2008. Mathematics for Elementary Teachers A Contemporary approach $8^{\text {th }}$ edition. New Jersey: John Wiley \& Sons, Inc.

Feist, J. \& Feist, G.J. 2011. Teori Kepribadian edisi 7. Terjemahan Handrianto. Jakarta: Salemba Humanika.

Fitria, C. 2014. "Profil Keterampilan Berpikir Kreatif Siswa dalam Memecahkan Masalah Matematika Ditinjau dari Tipe Kepribadian (Sanguinis, Koleris, Melankolis, dan Phlegmatis)." Jurnal Ilmiah Pendidikan Matematika. Volume 3 No. 3 Tahun 2014.
Huitt, W. 1992. "Problem-solving and Decision Making: Consideration of Individual Differences Using the Myers-Briggs Type Indicator." Journal of Psychological Type, 24, 33-44.

Keirsey, D. 1998. Please Understand Me II. Temperament Character Intelligence. USA: Prometheus Nemesis Book Company.

Manurung, O. 2011. Profil Kreativitas Penyelesaian Masalah Matematika Siswa SMP Berdasarkan Gaya Kognitif Reflektif dan Impulsif. Tesis tidak dipublikasikan. Surabaya: Unesa Pasca Sarjana Program Studi Pendidikan Matematika.

National Council of Teachers of Mathematics (NCTM). 2000. Principles and Standards for School Mathematics. United States of America: The National Council of Teachers of Mathematics, Inc.

Panjaitan, B. 2015. "Karakteristik Metakognisi Siswa dalam Memecahkan Masalah Matematika berdasarkan Tipe Kepribadian.” Jurnal Ilmu Pendidikan. Vol. 21 No.1. 20-23.

Permendikbud No. 58 Tahun 2014 Tentang Kurikulum 2013 Sekolah Menengah Pertama/ Madrasah tsanawiyah. Jakarta: Kemendikbud.

Prasetyo, A. Dwidayati, N.K. \& Junaedi, I. 2017. "Kemampuan Koneksi dan Disposisi Matematis Siswa Ditinjau dari Tipe Kepribadian Keirsey pada Pembelajaran Matematika Model Eliciting Activities.' Unnes Journal of Mathematics Education Vol. 6 No. 2 Agustus 2017.

Silver, E.A. 1997. Fostering Creativity through Instruction Rich in Mathematical Problem-solving and Thinking in Problem Posing, (Online), (http://www.fiz.karlsruhe.de/fiz/publications/zdm/zdm 973a3.pdf, accessed on November 3, 2018).

Siskawati, F.S. 2013. Penalaran Siswa SMP dalam Memecahkan Masalah Matematika Ditinjau dari Perbedaan Kepribadian Ekstrovert dan Introvert. Tesis tidak dipublikasikan. Surabaya: Unesa Pasca Sarjana Program Studi Pendidikan Matematika.

Sumardyono. 2004. Karakteristik Matematika dan Implementasinya Terhadap Pembelajaran Matematika. Yogyakarta: Depdiknas. 